\title{
The stakeholder theory of corporate control and the place of ethics in OHADA: The case of Cameroon
}

\author{
Author: \\ Irene Fokum Sama-Lang' \\ Abel Zesung Njonguo ${ }^{2}$

\section{Affiliation: \\ ${ }^{1}$ University of Buea, \\ Cameroon \\ ${ }^{2}$ Supreme Court of \\ Cameroon}

\section{Correspondence to:} \\ Prof. Irene Fokum \\ Sama-Lang \\ University of Buea, \\ P.O. Box 63, \\ Buea, Cameroon \\ E-mail: \\ finds_1999@yahoo.com \\ DOI:
}

10.15249/10-1-117

\section{Keywords:}

business; ethics; OHADA; stakeholder

\section{Abstract}

The rapid increase in globalisation in the last two and a half decades has resulted in a global culture of doing business. States respond to such flexibility by harmonising their business laws. Some of these laws are further supplemented by global values that are, in most cases, ethical. This article combines the stakeholder theory of corporate governance with ethical positivism to investigate the place of ethics in the OHADA member state of Cameroon. Using in-depth critical content analysis of primary and secondary data, it details the strengths and weaknesses of both models and shows the disconnection between the spirit and letter of OHADA laws. It further asserts that ethics is crawling into OHADA as a result of the forces of nature rather than the foresight of its architects. As such, the article puts forward some recommendations.

\section{Introduction}

With a wider and varied community of interests (shareholders, alter egos, employees, state, society and environment) affected by businesses nowadays, the role of ethics remains inevitable in the conduct of the latter. However, before seeking the finest possibilities of merging the two concepts (business and ethics), the case must be made of community law and business ethics in their sphere of coverage; in this case, the OHADA region.

OHADA is the French acronym for Organisation pour l'Harmonisation en Afrique du Droits des Affaires, which is also known in English as the 'Organisation for the Harmonisation of Business Laws in Africa' and occasionally referred to, by its English acronym, OHBLA. ${ }^{1}$ It is a system of business laws and implementing institutions adopted by seventeen West 
and Central African countries. ${ }^{2}$ In this study, 'business' is construed as the pursuit of commercial activities, whereby commerce is the buying and selling of goods and services. ${ }^{3}$ In similar manner, ethics is taken to mean an inquiry into the nature and grounds of morality, where morality is taken to mean moral judgments, standards and rules of conduct (Taylor, 1975:1). Narrowing this definition down to the focus of this study, Velasquez (1998:7) defines business ethics as the study of moral standards (right and wrong, good and evil) in so far as they apply to business.

This article posits that a proper analysis of ethical values as related to businesses in the OHADA region entails investigating the intersections between the stakeholder model of corporate governance and the conforming ethical theory (ethical universalism), justifying collective though varying interests. It then proceeds to a brief overview of the OHADA Treaty and Acts, pointing to the ethical dilemmas that attend it with reference to Cameroon, in particular with regard to the host state's attitude towards OHADA instruments, corporate social responsibility (CSR), and shared competence in business law. The paper concludes with some recommendations for improving the ethical landscape.

\section{Business ethics under the stakeholder theory of corporate control}

The stakeholder theory or model of corporate control presupposes that a company owes a wider duty to all who can affect and/or be affected by its act(s) and/or omission(s), and not just its shareholders. ${ }^{4}$ This theory comes to challenge the classical corporate control theory, better known in American literature (Gower, 1992:71; Martin \& Turner, 2009:253-254) as 'stockholder democracy', and in England as 'shareholder primacy'. It asserts that those who control and manage a company (be it directors, managers, the chief executive or executive directors) do so for the benefit of shareholders and are effectively accountable to them. Until the 1930's, and despite the fact that it had become commonplace for directors' reports to declare that they recognise owing duties not only to the shareholders but also the company's employees, customers and the community, it had not occurred to company lawyers, at any point in common law, that if there were any such duties, they had anything to do with company law. ${ }^{5}$

However, Gower (1992:71) notes that since then, stimulated by the writings of Berle and Means (1932) and the debate between Berle and Dodds (1931-32) in the Harvard Law Review, company lawyers have, often with misgivings, faced the possibility that these wider duties may be owed, and that public companies may have developed a social conscience. This 'econo-legal' debate has become an ongoing feature of what is broadly referred to as 'corporate governance', which includes a company's corporate social responsibility towards a wider stakeholder community, including, but not limited to, the state, their workers, the community and the environment.

Business ethics pundits posit that corporate social responsibility is multidimensional, with four constructs, namely economic, legal, ethical and voluntary philanthropic 
responsibilities (Carroll, 1989:30-33; Ferrell \& Fraedrich, 1997:6). Although these constructs may never be implemented on equal measure in any given business environment, it is difficult, if not impossible, to see a business operating nowadays without translating at least three of these constructs into concrete action or outcomes. This interwoven relationship between the shareholder and stakeholder models expose companies to a social conscience that can hardly be denied by proponents of pure stockholder democracy (Dimitriades, 2007). However, holding companies to each and every social responsibility they may have might not always fall within the ambit of the law, as they fluctuate from a low to high degree of socially acceptable organisational behaviours (Barney \& Griffin, 1992:734-735).

As a result, ethics require companies not only to know that they owe such duties, but also to perform their obligations. Based on this line of thought, Hunt and Vitell (1986:5-11) advance ethical positivism as a descriptive rather than prescriptive value standard to assist in ethical decision making. ${ }^{6}$ They argue that better decisions emanate from situations where one's ethical thought process is guided rather than being presented with a list of prescribed norms and standards. Thus, whereas the law prohibits companies from engaging in acts of bribery and corruption, the same law will not compel a company to sponsor water projects or build schools in the locality where it operates. It is the company's knowledge of right and wrong, good and evil, as related to its objectives and sphere of operation, that will compel it to act. Based on this interconnection between the stakeholder model of corporate governance and the theory of ethical positivism, the position of OHADA will be analysed in order to determine its responsiveness to such values in Cameroon.

\section{OHADA legislation}

Signed on 17 October 1993 by fourteen African heads of state, the Treaty on the Harmonisation of Business Laws in Africa ${ }^{7}$ (OHADA Treaty) was established as an institution and vested with rights and duties separate and distinct from those of its founding members (Martor, Pilkington, Seller, \& Thouvenot, 2007:1). The treaty, which was signed at Port Louis (Mauritius), went into force on 18 September 1995. Article 2 of the OHADA Treaty (herein after called the 'Treaty') gives the institution an express mandate to legislate on business law or any other matter unanimously deemed by the Council of Ministers as falling within the domain of business law. As such, Acts enacted for the adoption of common rules will, according to Article 5 of the Treaty, be referred to as 'Uniform Acts'. 8

To allow it to properly exercise its functions, Articles 27-41 of the Treaty gives OHADA a quadruple institutional setting, which splits it into the Council of Ministers, the Common Court of Justice and Arbitration, the Permanent Secretariat, and a regional training centre for staff and judges.

Uniform Acts have direct applicability in member states once they are enacted. Article 10 of the Treaty stipulates that "Uniform Acts are directly applicable and 
overriding, notwithstanding any conflict they may give rise to in respect of previous or subsequent municipal laws". This unambiguous and clear language denotes two important requirements in the relationship between OHADA as a supranational body of laws and member states as recipients of the instruments of application. First, the article strengthens the position of OHADA laws by stating that they shall have direct effect on Member States once enacted. Secondly, it situates the hierarchy of same by stating that their applicability override domestic laws, notwithstanding any retrospective or future conflict between the two.

The importance of this article cannot be overstated, as it builds the bridge that connects OHADA to the member states. As will be demonstrated below, the attitude of host states may pose problems when it comes to interpretations based on the spirit of the law, on the one hand, and the letter of the law, on the other. In fact, an analysis of these conflicts will demonstrate the ethical problems attendant upon the bi-jural application of community laws in a state such as Cameroon, with its twin common and civil law foundations.

In the words of the chief architect of OHADA, Judge Keba Mbaye, the organisation serves as a legal tool for economic integration and development in West and Central Africa, as there can be no economic integration without legal integration (Martor et al., 2007:VII). Among other things, OHADA was designed to facilitate cross-border trade and create conditions for free competition through the establishment of legal texts that are technically simple and efficient (Mouloul, 2009:10). Another advantage envisaged by its founders is the relocation of large companies in Africa through the encouragement of arbitration as a discrete means of dispute resolution. Politically, they foresaw this as an opportunity to avoid having conflicting laws in the harmonised areas of business law and to promote African unity (ibid). However, this article posits that instead of achieving the stated objective, OHADA has, arguably rendered the applicability of legal principles in the domain of business law more complex in some member states.

\section{Host state's attitude}

The selection of Cameroon as a test case for the importation of business ethics in the form of OHADA is not random. The country has a historical bi-jural culture of civil and common law traditions that are still in practice today. These systems of law each have unique attributes that can seldom, if ever, be reconciled when they meet at a cross roads, not to mention their receptiveness to ethical values pertaining to business. Despite their judicial disparity, Cameroon has a single constitution that serves as the primary law of the land. Whereas this document renders the 'letter of the law' the same under both systems, the 'spirit of the law' is subject to inconsistencies in the standards applied in the Francophone and Anglophone regions.

Directly linked to Article 10 of the OHADA Treaty is Article 45 of the 1996 Constitution of Cameroon (as amended) (herein after called the 'Constitution'), which legislates that "duly ratified treaties or international agreements shall, following their publication, override national laws, provided the other party implements them". This provision 
accords a supranational status to OHADA legislation and grants it legal priority should it conflict with any domestic legislation. This is the letter of the law in action. In fact, the provision pragmatically aims at harmonising and integrating legal rules for the conduct of business in the country.

Although this letter of the law has been welcomed under both legal systems, its manner of application has been one of constant criticisms. Challenges encountered by civil law judges in the Francophone region are minimal and often trivial, perhaps due to the familiarity of the civil law-inspired formulation and application of OHADA texts. As a result of the common law's attachment to doctrines and principles, as well as the importance of precedence, common law courts, by contrast, have met with difficulties in easily accepting and applying OHADA laws. They challenge the constitutionality of OHADA legislation in Anglophone Cameroon, ${ }^{9}$ on several grounds.

In the first place, Article 42 (original) of the OHADA Treaty states that French will be the working language of the Treaty. This forms a sharp contrast with and utterly disregards Article 1(3) of the Constitution, which stipulates that English and French will be the official languages of the country. The same provision puts the burden on the state not only to guarantee bilingualism, but also to promote and protect national languages. In fact, the Constitution, which represents the grundnorm of the country from which every other law draws its validity, recognises the bilingual heritage of the country in the opening statement of the preamble: "We the people of Cameroon, proud of our linguistic and cultural diversity, an enriching feature of our national identity [...]."

Article 65 of the Constitution reaffirms the need to maintain the linguistic and cultural diversity of the country, as acknowledged in the preamble. Moreover, Article 68 confirms the validity of federal and state laws that existed before 1996, provided they are not repugnant to the Constitution and have not been amended by national laws or regulations; hence, the provisions of Article 46 of the Federal Constitution of 1 September 1961 and Article 38 of the Unitary Constitution of 2 June 1972, pertaining to the protection of Cameroon's linguistic heritage, remain valid and cannot be challenged by any OHADA instruments of application. Jean-Claude Gémar (in Melong, 2013:2) characterises this as the "inextricable link" between language and law, and argues that it leads to shortfalls in the functional equivalence of the French source text and the English translation. In fact, in Akiangan Fombin Sebastien v. Foto Joseph \& Others, ${ }^{10}$ Justice Ayah Paul, sitting at the High Court in Kumba, questioned the constitutionality of OHADA law in Anglophone Cameroon. His Lordship criticised OHADA as a piece of legislation that was allowed into Anglophone Cameroon through the back door. Citing the arguments enunciated above, he further referred to Article 36(1)(b) of the Constitution, which allows the President of the Republic to submit to referendum, after consulting with the Senate, National Assembly and Constitutional Council, any issue considered to be of paramount importance to the nation; in particular, international agreements and treaties. As such, Justice Ayah Paul argued that OHADA ought to have been put to a referendum before being ratified by Decree No 96/177 of 5 September 1996. 
Although the Kumba High Court's reasoning holds pride of place in safeguarding the linguistic and cultural heritage upon which Cameroon's judicial systems are based, it has some lapses in relation to the Constitution. Questioning the constitutionality of OHADA law in Anglophone Cameroon is a fallacy of division that looks secessionist in form. Though administered by two distinct legal systems, the Constitution, in the first paragraph of the preamble, recognises Cameroon as "one and the same nation, bound by the same destiny". On this premise, the court ought to have questioned the constitutionality of OHADA law for the nation as a whole, not only Anglophone Cameroon. Besides, Article 46 of the Constitution gives the Constitutional Council the sole responsibility to rule on matters pertaining to the Constitution, without calling for the assistance of the courts. Only the President of the Republic, National Assembly and Senate can refer matters to the Constitutional Council (Tumnde, 2002:27-29). As democratic institutions have not been fully developed in Cameroon, the Supreme Court sits in place of the Constitutional Council. Tumnde contends that this complicates attempts at reform, as the persons or bodies with the power to do so are the very ones behind OHADA law.

From a positivist standpoint, and holding true to the conviction that language and law are inextricably linked, one must commend the decision of Justice Ayah Paul in Akiangan Fombin Sebastien v. Foto Joseph \& Others for raising not only technical issues (in a system that blends civil and common law), but also ethical questions. If one were to fragment ethical positivism into its deontological and teleological frameworks, it would, arguably, be safe to say that the civil law system of Cameroon is more deontological. It holds the Uniform Acts as the legal standard, so that whatever substantive and procedural law considered to be right in terms of the Uniform Acts is taken as right, and whatever is considered wrong, is wrong. Where does that leave those who adhere to a different system than that on which the Uniform Acts are based, as is the case of Anglophone Cameroon? How can this be reconciled with a system that adopts a teleological approach by focusing on the consequences of OHADA Uniform Acts? These different perspectives on ethical problems will most likely result in different ethical solutions and outcomes. Hunt and Vitell (1986:3) point to the weakness of an ethical model based solely on an inherent standard created by a norm. Yet, they maintain that ethical positivism is the best approach, as it looks at both the norm and the possible outcomes which it can produce.

Given that the common law is founded on principles that allow judges wider latitude to question the legality of a given law, one can say that the OHADA law strips Anglophone Cameroon of its common law essentials and systematically displaces the ethical foundation upon which this system is based. Even so, Melong (2013:4) decries the lack of a standard translation technique in the OHADA system, blaming this as the principal reason for the multiple and varied translated texts, with no 'official' version. Could this be ascribed to a lack of expert translators; the ambiguity of the objective of Article 2 of the OHADA Treaty; or the curriculum at the OHADA training centre, ERSUMA?

Despite the Kumba High Court ruling on the illegality of the OHADA law in 2000, and the revision in 2008 of the OHADA Treaty to add English, Spanish and Portuguese to French as official languages under Article 42, much remains to be done. Contrary to 
the text and spirit of the revised Article 42, new Uniform Acts are routinely launched in French and only become available in other official languages at some later date, if ever: years after their adoption in 2004 and 2010, respectively, the Uniform Act on the Carriage of Goods by Road and the Uniform Act on Cooperatives are still only available in French on the official OHADA website. Likewise, at the time of writing, in spite of continued assurances that the English, Spanish and Portuguese portals on the ERSUMA website "will be available soon", the French portal remains the only functional one. Such glaring inequality in the treatment of the various languages (and by extension cultural) groups leaves one wondering whether the revision to Article 42 is but a device to placate contrary voices, or a reflection of OHADA's true commitment to inclusiveness, aimed at serving the interests of all stakeholders. And if the latter is true, how soon is 'soon'? How long will it take before the values upon which the common law is founded are safeguarded in text and application? How soon shall equality be accorded to all the cultures that make up OHADA?

The lack of legal clarity seem to be intrinsic to community law. A similar lack of precision in European Union community law prompted Lord Denning MR, in his judgment in Bulmer v. Bollinger, ${ }^{11}$ to caution English lawyers on the lapses of community law:

[C]ommunity law expresses its aims and purposes in sentences of moderate length and commendable style, but it lacks precision. An English lawyer would look for an interpretation clause, but he would look in vain. There is none [...]. There are gaps and lacunae which must be filled by the judges, or by regulations or directives. It is the European way.

The case of Bulmer v. Bollinger illustrates the impact of community law in the context of the host state, a scenario that also obtains in the common law regions of Cameroon. The case highlights the fact that community law leaves much to chance, and that in seeking to harmonise common practices, it opens the way for much legal wrangling in the courts. To take one recent example: In 2015, with tension mounting in the North West region of the country over an unwritten law compelling lawyers to make court submissions in French, despite the fact that the region is English-speaking, lawyers from this region moved to paralyse the courts before the matter was resolved. ${ }^{12}$

Compelling lawyers in the English-speaking regions to use French in court was seen as a move "to systematically kill the Anglophone judicial system or the common law practice in the country", ${ }^{13}$ a blatant display of power hungriness and utter disregard not only of Article 68 of the Constitution of Cameroon - which provides for the continued existence of laws in the former federated states, provided that they do not contradict the Constitution and have not been repealed by any subsequent law - but also of the English language that forms the bedrock of the common law system. Should it really be necessary for lawyers to negotiate a temporary peace deal with the President of the North West Court of Appeal, or to remind his Lordship of the grundnorm that binds the nation? 
The issues raised in the preceding paragraphs underscore some of the difficulties that may arise in the course of reaching a legal and or ethical judgment. Engel, Blackwell and Kollat (1978) and Howard and Sheth (1969), quoted in Hunt and Vitell (1986:9) argue that such judgments will impact on behaviour based on the intervening variable of intentions. In the case discussed above, the intention of the Anglophone lawyers was to safeguard the common law heritage of the English-speaking region, whereas that of the President of the North West Court of Appeal was, arguably, to work in a more 'comfortable' language essentially obviates the essential feature of the common law: the English language. Different or opposing intentions will invariably produce controversial outcomes. It therefore seems unsurprising that Anglophone lawyers regularly raise issues aimed at creating awareness and advocating for equal treatment.

\section{Corporate social responsibility}

Managing ethical behaviour is one of the most pervasive and complex problems facing business organisations today (Stead, Worrell \& Stead, 1990:233). Researchers have identified a myriad of factors accounting for this problem, one of which is the locus of control (Levenson, 1974:377-383). Locus of control is the degree to which people believe that they have control over the outcome of events in their lives (internal), as opposed to being at the mercy of external forces beyond their control, such as luck, fate or powerful others and institutions. These internal and external factors underscore employees' attitude toward an organisation, on the one hand, and managers' ability to influence outcomes through their personalities, on the other. This takes ethics beyond compliance requirements set out in law and justifies the need for company codes to outline and provide guidance for obligations of this nature. Given that most of the provisions contained in a company code of ethics are only enforceable internally, much remains to be desired in this regard in the OHADA region in general, and Cameroon in particular, where these broad-based ethical business practice is underdeveloped and sometimes feigned (Ndzi, 2016:153).

It is important to note that OHADA laws are enforced in a region whose member states are rated among the most corrupt countries on earth, with Cameroon, placed 144th out of 175 countries surveyed for public corruption. ${ }^{14}$ Hegarty and Sims (1979) assert that character and background determine people's behaviour patterns and influence their sense of judgment. Although the business character of both the public and private sectors of Cameroon ostensibly reflects a culture of fair standards, dubious practices are 'allowed' as a quid pro quo to achieve high earnings. This double standard means that businesses may meet the strict letter of the law, but will be less inclined to achieving what John Stuart Mill called the summum bonum, or greatest good for the greatest number. In a recent case, ${ }^{15}$ the applicant, a multinational corporation, had taken advantage of the corrupt nature of the country to manoeuvre its way through the system and began operating a palm oil business without carrying out an environmental impact assessment (EIA), a prerequisite for the approval of the operation. The court issued an injunction compelling it to conduct a proper EIA before operations could continue. 
Another high-risk ethical environment in the OHADA region is the microfinance sector, which is regulated by the Central African Banking Commission (COBAC). ${ }^{16}$ Having served as legal adviser to two microfinance establishments subject to COBAC compliance rules, the co-author contends that most managers and high-ranking board members of the former are found wanting in terms of the utilitarian rule. Their display of ethical egoism, using their credit union as a front to promote selfish interests, is alarming. They award loans to friends and relatives, negotiate kickbacks in union deals, use union money to finance personal projects, and above all, manipulate their financial records to hide any traces of wrongdoings. ${ }^{17}$

The sad irony is that these are the people who are entrusted with the vision of their credit unions; individuals who command respect and trust. The argument could be advanced that people learn appropriate behaviour by modelling the behaviour of others whom they consider as important: parents, siblings, peers, teachers, superiors, and so forth (Luthans $\&$ Kreitner, 1975). As powerful superiors, these managers and board members, by virtue of their position, wield great influence in shaping, either directly or indirectly, decisions in the boardroom. They become so powerful through the malpractices they commit in the union's name, that they inspire others to vie for membership to the board as well, so as to serve their own selfish interests and secure unlawful proceeds for themselves while ostensibly advocating on behalf of the credit union and its members.

Globalisation raises further ethical issues. The growth of multinationals and the increase in cross-border trade through regional partnerships and licensing agreements has led to a global culture of doing business (Kidder \& Cleveland, 1994). This imports supranational ethics into domestic practices, which tend to directly or indirectly influence local practices. A case in point is BICEC Bank, a member of the Groupe Banque Populaire, with its head office in France. BICEC was identified in a 2007 International Monetary Fund (IMF) working paper ${ }^{18}$ as the biggest bank, with the highest capital assets, in Cameroon. Yet it maintains lower ethical standards, not only compared to Banque Populaire in France, but a host of other commercial banks in Cameroon..$^{19}$ Long queues, poor customer service, and frequently defective automatic teller machines (ATMs) are but a few of the service shortfalls that customers suffer on a daily basis in Cameroon, but which are hardly seen in France. Moreover, BICEC's ATMs have very limited functionality (they usually offer only a withdrawal and/or account balance option), unlike its French counterpart, whose ATMs provide customers with a range of easily accessible banking services, including deposits, payments, detailed statements, etcetera. In fact, they replace in-branch service in most aspects of banking life in France. As most ethical principles are moral rather than legal in nature, they are difficult to enforce, and those who are most adversely affected by ethical lapses are often also the ones who are most powerless to enforce them. For this reason, the burden of creating and implementing codes of ethics for better standards in business falls on corporations and regulatory bodies. 


\section{Shared competence in business law}

The proper interpretation of Articles 2 and 10 of the Treaty implies a continuation of national laws where no Uniform Act has been adopted to cover a particular area of business law. While this study focuses on Cameroon, the provisions of these articles make the discourse on labour and employment relations law a worthwhile subject for analysis across the entire OHADA community.

Skewed labour relations and a high rate of unemployment, coupled with a $2.9 \%$ inflation rate in 2015, make labour law reform a pressing matter in Cameroon. ${ }^{20}$ Njonguo (2014:112) characterised the 2014 shift in the guaranteed minimum wage (GMW) from 28,216 FCFA to the current 36,270 FCFA as a hostile act of the state with an oversight effect of placing workers at the mercy of powerful employers. Other monthly GMWs in the OHADA community are at similar levels: Benin - 40,000 FCFA; Central African Republic $-8,500$ FCFA in the agricultural sector and 26,000 FCFA in the public sector; the Republic of Congo - 5,000 FCFA; and Ivory Coast - 36,607 FCFA. ${ }^{21}$ Most of these rates were established years ago and do not reflect the current socioeconomic reality in the region (Njonguo, ibid).

As a point in case, the GMW of 36,270 FCFA which was introduced in Cameroon in 2014 is not sufficient to support a rural family of five for two weeks (2014:112). If the GMW remains at this level while the cost of living keeps rising, life will become increasingly hard for minimum wage workers: shelter and education will become difficult to afford, ${ }^{22}$ healthcare will become a luxury, and transportation will be a nightmare. Yanou (2009:40-42) calls this "contemporary slavery", which is allowed to continue despite Cameroon's commitment in the preamble to the Constitution, the Universal Declaration of Human Rights (UDHR), Article 23(3) of which recognises the right of every worker to receive a fair and favourable remuneration, capable of providing them and their dependents with the means to live with basic human dignity. Whether the GMW does in fact allow the majority of workers in Cameroon (especially in the informal sector) and their families to live a dignified life is hardly open to debate - any objective mind should be able to see that it represents a collapse of ethics in its legal and moral form, perpetrated by the law itself. In essence, the spirit of the law cannot conform to acceptable ethical norms if the system of the law is itself a violation of the wider community of interests which the stakeholder theory seeks to protect.

The question whether one Uniform Act is more important than another has frequently been posed. But one may equally ask why there should be several Uniform Acts addressing the immediate needs of business and investors, yet no corresponding Act to serve the interests of the workers whose services are essential to the success of these businesses? In this regard, the fourth paragraph of the OHADA Treaty, which refers to "a simple, modern and adaptable [...] business law", surely does not meet the expectations of the stakeholder theory of corporate control, which implies a body of laws where all stakeholders are appropriately taken into account. 
On the contrary, the spirit of the OHADA Treaty shows wilful neglect of areas that may pose problems for profit-hungry investors. The third line of the preamble to the Treaty, which holds that "membership in the Franc zone is an economic and monetary stability factor and constitutes a major asset for the progressive realisation of [member states'] economic integration", contains more than a hint of lobbying by big businesses to secure a body of law that directly protects their interests. Indeed, French businesses are said to benefit most from such a fluid system, since France manages the foreign reserve of the CFA franc countries and therefore wields great influence within the OHADA arena (Bennyworth, 2011). Thus, it is argued that OHADA is an African law, but not of Africa, as it is designed to protect business, rather than to address the realities of job creation and security in its sphere of operation. This makes it ethically weak.

\section{Conclusion}

The vision of the architects of OHADA to seek harmonisation of business law and subsequent integration in the region has, to a remarkable extent, been realised. OHADA has brought about economic integration and has also created a higher degree of certainty for businesses in member states than was previously the case. However, these achievements seem to be felt more by French-speaking member countries than their nonFrench-speaking counterparts. The reason is self-evident: OHADA is basically civil-law inspired, and its primary language of use is French. This makes it easy for its provisions to be transposed into the national legislation of French-speaking member states. Again, ethical values associated with the civil law system will readily fit into this community law and adaptively applied.

Non-French-speaking states and regions like Equatorial Guinea, São Tomé and the English regions of Cameroon, however, find it difficult to accord the same degree of success to the OHADA law. As mentioned in this study, despite the revision of Article 42 of the OHADA Treaty, in terms of which French, English, Spanish and Portuguese enjoy equal status as official languages, Uniform Acts continue to be drafted in French, with translated versions only becoming available at some later time, when the French version has already been widely circulated, as is the case with the Uniform Acts on Cooperatives and on the Carriage of Goods by Road, whose translated versions have yet to be made public. This is not only bad in form, but also in effect, as it creates a certain division among member states, with some states and regions apparently enjoying a higher status than others. It is therefore crucial that certified translated versions of Uniform Acts not only be made available at the same time as the French, but also that they be equally accessible.

Similarly, this study shows that instead of adopting a hybrid model of African business law, OHADA robs Anglophone Cameroon of its common law culture by systematically wiping out the principles upon which this system is based. To rectify this situation, OHADA should adopt a truly unifying model, where all stakeholders are taken into account. An important element of such a model would be the appointment of common law judges to consider common law appeals in the Common Court of Justice and Arbitration. 
Though Uniform Acts are progressively covering the domains of business law stipulated in Article 2 of the OHADA Treaty, national laws in areas of business law where Uniform Acts are yet to be legislated tend to create many imbalances and uncertainties, which affect OHADA's credibility. In the domain of labour and employment law, undignified and outdated guaranteed minimum wage legislation in Cameroon and other member states continue to put workers at the mercy of employers through unequal bargains. This study identifies poverty, limited access to formal education and poor healthcare as some of the ills resulting from low wages, and urges the Council of Ministers to hasten their efforts towards creating a Uniform Act on Labour to address this problem.

Finally, ethics imported into the region through multinationals must be cautiously applied, so as not to overstate its role or allow it to be used to achieve ulterior motives.

In conclusion, it is the finding of this study that OHADA is stuck between the common and civil law systems in Cameroon, which makes it very difficult to adopt a hybrid model onto which ethical values can readily be transposed. The fact is that while business ethics is steadily expanding its reach and assuming greater importance in the OHADA region, this might be the result of natural forces, such as globalisation, rather than the vision of its architects.

\section{References}

Barney J.B. \& Griffin W.R. 1992. The management of organizations: strategy, structure, behavior. University of Michigan, Houghton Mifflin.

Bennyworth, I.J. 2011. The Ongoing relationship between France and its former African colonies. http://www.eir.info/2011/06/11/the-ongoing-relationship-between-france-and-its-former-african-colonies/ [Accessed: 13 September 2016].

Brener, S.N. \& Molander, E.A. 1977. Is the ethics of business executives changing? Harvard Business Review, 55(January-February):57-71.

Cameroon Web. 2015. Bar Council resolves language dispute in court. http://www.cameroonweb.com/ CameroonHomePage/regional/artikel.php?ID=321067 [Accessed: 13 September 2016].

Carroll, A. 1989. Business and society: Ethics and stakeholder management. Cincinnati, OH: South-Western.

Dimitriades, Z.S. 2007. Business ethics and corporate social responsibility in the e-economy: A commentary. Electronic Journal of Business Ethics and Organization Studies (ejbo), 12(2).

Dubinsky, A.J., Berkowitz, E.N. \& Rudelius, W. 1980. Ethical problems of field sales personnel. MSU Business Topics, (Summer):11-16.

Engel, J.F., Blackwell, R.D. \& Kollat, D.T. 1978. Consumer behaviour. 3rd Edition. Hinsdale, IL: Dryden.

Ferrell, O.C. \& Fraedrich, T. 1997. Business ethics. Boston, MA: Houghton Mifflin.

Gower L.C.B. 1992. Principles of Modern Company Law. London: Sweet and Maxwell.

Hegarty, W.H. \& Sims, H.P., Jr. 1979. Organisational philosophy, policies and objectives related to unethical decision behavior: A laboratory experiment. Journal of Applied Psychology, 64(3):331-338. DOI: 10.1037/0021-9010.64.3.331

Howard, J.A. \& Sheth, J.N. (1969). The theory of buyer behavior. New York, NY: Wiley.

Hunt, S.D. \& Vitell, S. 1986. A general theory of marketing ethics. Journal of Macromarketing, 6(1):5-16. DOI: $10.1177 / 027614678600600103$ 
Index Mundi. 2014. Cameroon Economy Profile. http://www.indexmundi.com/cameroon/economy_profile. html [Accessed: 13 September 2016].

Kidder, R.M. \& Cleveland, H. 1994. Shared values for a troubled world: Conversations with men and women of conscience. Forest City, NC: Fireside Books.

Levenson, H. 1974. Activism and powerful others: Distinction within the concept of internal-external control. Journal of Personality Assessment, 38:377-383. DOI: 10.1080/00223891.1974.10119988

Luthans, F. \& Kreitner, R. 1975. Organizational behavior modification and beyond: An operant and social learning approach. Glenview, IL: Scott Forsman.

Martor, B., Pilkington, N., Seller, D.S. \& Thouvenot, S. 2007. Business Law in Africa: OHADA and the Harmonization Process. London: GMB Publishing.

Melong, J. 2013. Implementation of Ohada laws in a bilingual and bijural context: Cameroon as a case in point. Revue de l'ERSUMA: Droit des affaires - Pratique Professionnelle, No 2, Etudes. http://revue.ersuma. org/no-2-mars-2013/etudes-21/Implementation-of-Ohada-laws-in-a [Accessed: 10 June 2016].

Mouloul, A. 2009. Understanding the Organization for the Harmonization of Business Laws in Africa (OHADA). 2nd Edition. http://www.ohada.com/content/newsletters/1403/Comprendre-I-Ohada-en.pdf [Accessed: 13 September 2016].

Murphy, P.E. \& Laczniak, G.R. 1981. Marketing ethics: A review with implications for managers, educators and researchers. In: B.M. Enis \& K.J. Roering (eds.). Review of Marketing. Chigago, IL: AMA. 251-256.

Ndzi E. 2016. Corporate social responsibility in Cameroon: The hydroelectricity sector. African Journal of Business Management, 10(7). http://www.academicjournals.org/journal/AJBM/article-full-textpdf/5DAED9157811 [Accessed: 13 September 2016].

Njonguo, A.Z. 2014. The protection of workers' rights in Cameroon under the International Labour Organisation's Tripartite Consultation Convention, 1976. Unpublished LLM thesis. University of Buea, Buea.

OHADA. 2008. The OHADA Treaty. http://www.ohada.com/traite.html [Accessed: 12 September 2016].

Sheth, J.N. 1967. A review of buyer behaviour. Management Science, 13(August):B719-B756.

Stead, W.E., Worrell, D.L. \& Stead, J.G. 1990. An integrative model for understanding and managing ethical behaviors in business organizations. Journal of Business Ethics, 9(3):233-242. DOI: 10.1007/BF00382649

Taylor, P.W. 1975. Principles of ethics: An introduction. Encino, CA: Dickenson Publishing Company, Inc.

Transparency International. 2013. Corruption perception index. http://www.ey.com/Publication/vwLUAssets/ EY-Transparency-International-Corruption-Perceptions-Index-2013/\$FILE/EY-TransparencyInternational-Corruption-Perceptions-Index-2013.pdf [Accessed:13 September 2016].

Tumnde, M.S. 2002. The applicability of the OHADA treaty in Cameroon: Problems and prospects. Annales de la Faculté des Sciences Juridiques et Politiques, 6:1-7. Yaounde, CMR: Presse Universitaire d'Arique. http:// biblio.ohada.org/pmb/opac_css/doc_num.php?explnum_id=902 [Accessed: 13 September 2016].

Velasquez, M.G. 1998. Business ethics: Concepts and cases. 7th Edition. Upper Saddle River, NJ: Pearson.

Yanou, M.A. 2009. Labour law: Principles and practice in Cameroon. Buea: REDEF Publishers.

\section{Endnotes}

1 http://www.ohada.com/jurisprudence/ohadata/J-10-122.html [Accessed: 13 November 2015].

2 Member states include Benin, Burkina Faso, Cameroon, the Central African Republic, Chad, Congo, the Democratic Republic of Congo, Equatorial Guinea, the Federal Islamic Republic of the Comoros, Gabon, Guinea, Guinea Bissau, Ivory Coast, Mali, Niger, Senegal and Togo.

3 http://www.merriam-webster.com/dictionary/commerce [Accessed: 05 July 2016]. 

Governance [Accessed: 27 November 2015].

5 See, for example, the decision in Percival v. Wright [1902] $2 \mathrm{CH} \mathrm{401,} \mathrm{and} \mathrm{Dillon} \mathrm{L.J.,} \mathrm{in}$ Multinational Gas \& Petroleum Chemical Co v. Multinational Gas Petrochemical Services Ltd. [1983] CH 258.

6 This model is grounded on two major frameworks in moral philosophy: the deontological and teleological ethical standards. The main difference between the two is that deontological theories focus on specific actions (the inherent rightness or wrongness of a norm), while teleological theories focus on the consequences of such actions. For its part, ethical positivism suggests a combination of these standards in addressing any problem with an ethical content.

7 The full text is available at http://www.ohada.com/traite.html [Accessed: 12 September 2016]. The text of the original OHADA Treaty is available at the OHADA Secretariat in Yaounde, Cameroon; the Common Court of Justice and Arbitration (CCJA) in Abidjan, Ivory Coast; and the OHADA Training Centre (ERSUMA), in Porto Novo, Benin.

8 At present, there are eight Uniform Acts: the Uniform Act on General Commercial Law; the Uniform Act on Commercial Companies and Economic Interest Groups; the Uniform Act on Simplified Recovery Procedure and Measures of Execution; the Uniform Act on Collective Proceedings for Wiping Off Debts; the Uniform Act on Accounting; the Uniform Act on Arbitration; the Uniform Act on Securities; the Uniform Act on Cooperatives; and the Uniform Act on the Carriage of Goods by Road.

9 Formerly the Federal Republic of Cameroon, which was administered by the British as a trust territory of the United Nations until it gained independence in 1960, when it opted to unite with the Republic of Cameroon (a French trust territory of the United Nations). In consequence, the common law was also instituted in Anglophone Cameroon.

$10 \mathrm{HCK} / 3 / 96$ of 6 January 2000.

11 Bulmer v. Bollinger, 1974, Chapters 401-418.

12 http://www.cameroonweb.com/CameroonHomePage/regional/artikel.php?ID=321067 [Accessed: 20 March 2015].

13 ibid.

14 Amnesty International, 2013, pp. 6-7. http://www.ey.com/Publication/vwLUAssets/EYTransparency-International-Corruption-Perceptions-Index-2013/\$FILE/EY-TransparencyInternational-Corruption-Perceptions-Index-2013.pdf [Accessed: 29 March 2015].

15 SG Sustainable Oils Cameroon Ltd v. Struggle to Economize Future Environment (SEFE), $\mathrm{HCN} / 03 / \mathrm{OS} / 2011 / 4 \mathrm{M} / 2012$ (unreported).

16 The Central African Banking Commission (COBAC) is the authority that ensures that microfinance establishments in the Economic Community of Central African Sates (CEMAC) have proper and up-to-date accounting and financial records.

17 For reasons of confidentiality and pending judgments in a number of related court cases, the authors prefer to state the general state of affairs. For more information, readers are referred to the 2008 Auditor's Reports for Buea P \& T Cooperative Credit Union Ltd. (p. 5) and the Buea Police Cooperative Credit Union Ltd., as well as the 2008 Auditor's Report for Mutengene Savings and Loans Cooperative Society, pp. 5-7.

18 See page 8 of the report found at https://www.imf.org/external/pubs/ft/wp/2007/wp0703.pdf 
19 Based on observations in the field by the authors as well as interviews with officials of Banque Populaire Loire et Lyonnais in France who prefer to remain unidentified.

20 See Index Mundi at http://www.indexmundi.com/cameroon/economy_profile.html [Accessed: 31 March 2015].

21 A global list of GMWs may be found at http://www.nationmaster.com/country-info/stats/ Labor/Salaries-and-benefits/Minimum-wage [Accessed: 13 September 2016].

22 Although government's policy on education is free tuition, secondary school pupils are subject to a Parents Teachers Association (PTA) fee that is equal to $60-70 \%$ of the monthly GMW. 
